\title{
PENTINGNYA PENDIDIKAN HUKUM TERHADAP SISWA MELALUI PELAJARAN PPKn (STUDI SMPS ISLAM BABUSSALAM KEC. BAGAN SINEMBAH)
}

\section{THE IMPORTANCE OF LEGAL EDUCATION TO STUDENTS THROUGH PPKn STUDY (ISLAMIC BABUSSALAM JUNIOR HIGH SCHOOL BAGAN SINEMBAH)}

\author{
TONI ${ }^{1 *}$ ), AGUS ANJAR ${ }^{2}$ ) \\ 1,2) STKIP Labuhan Batu, JI. SM Raja, No.126 A, Km 3,5, Aek Tapa Rantau Prapat. Indonesia \\ Email : toni300586@gmail.com
}

\begin{abstract}
Abstrak. Maju mundurnya suatu negara berada pada generasi yang mempunyai pendidikan yang lebih baik, terkhusus kepada siswa yang masih menimbah ilmu pendidikan disekolah. Maka untuk itu dibutuhkan sumber daya manusia yang berkualitas. Untuk mendapatkan hasil yang lebih baik perlu diberikan pendidikan hukum terhadap siswa melalui pelajaran PPKn. Materi tersebut harus diberikan semenjak pendidikan disekolah formal. Dapat kita lihat berkembangnya zaman serba modern banyak generasi bangsa yang tidak dapat menyaring aspek negatif dan positif dari setiap perkembangan zaman. Banyak kita lihat pergaulan tidak baik yang menjadikan generasi hancur dari masa depanya. Jenis Penelitian ini Deskriftif Kualitatif, metode pengambilan data dilakukan dengan In-depth interview, dan pemberian angket kepada siswa kelas VII, VIII.dan IX tentang Pentingnya Pendidikan Hukum melalui pelajaran PPKn. Data akan dianalisis dengan menggunakan metode kualitatif model Miles dan Huberman. Hasil penelitian didapatkan bahwa siswa cukup memahami pelajaran pendidkan hukum dengan baik walaupun masih adanya beberapa siswa yang masih belum paham tentang hukum. Dapat dilihat dalam angket siswa yang melakukan Sering total: (10,2\%), Kadangkadang total: $(23,2 \%)$, Selalu total: ( $14,2 \%)$, dan Tidak perna: $(17,8 \%)$. Dapat disimpulkan dari angket bahwa siswa cukup memahami dan dapat dilihat dari keterangan angket tentang pendidikan hukum.
\end{abstract}

Keyword: Siswa, Pendidikan Hukum, Guru

\begin{abstract}
Abstrak. a country with forward in a generation that has better education, especially for students whom hoarding education in school. So, we need quality human resources. It is necessary to provide legal education to students through PPKn lessons. The material must be given since formal school education. In the modern era of many generations we saw the development of the nation that cannot filter out the negative and positive aspects of every age development. Many of us see bad relations that make the generation destroyed the future. This type of research is descriptive qualitative, the method of data retrieval is done by in-depth interviews, and the provision of questionnaires to students of class VII, VIII and IX about the importance of legal education through lessons PPKn. Data was analyzed using qualitative methods of Miles and Huberman models. The results revealed that students have understood the education law with categories enough even though there were still some students who still did not understand the law. Can be seen in the questionnaire of students with categories often have total percentage $(10.2 \%)$, rare $(23.2 \%)$, Always $(14.2 \%)$, and Never: $(17.8 \%)$. It can be concluded from the questionnaire that students understand enough and can be seen from the questionnaire information about law education.
\end{abstract}

Keyword: Students, Law Education, Teacher 
Hal : $13-20$

\section{PENDAHULUAN}

Pendidikan Hukum perlu ditananamkan disekolah hal tersebut bertujuan untuk menambah wawasan dan ilmu pengetahuan yang dapat memberikan kontribusi pengetahuan hukum terhadap siswa. Pendidikan hukum tersebut dapat diberikan melalui materi pelajaran PPKn disekolah. Pendidikan merupakan sarana tempat menimbah ilmu pengetauan, untuk itu dunia pendidikan tidak dapat dipisahkan dari sekolah, baik pendidikan sekolah dasar, sekolah menengah pertama dan sekolah menengah atas atau sekolah menengah kejuruan. Untuk itu sekolah memegang peranan strategis dalam pengembangan ilmu pengetahuan bagi siswa, pendidikan sebagai proses upaya melahirkan generasi yang mempunyai akhlak dan budi pengerti yang baik, untuk itu perlu ditanamkan pengetahuan pendidikan yang tepat seperti memberikan pendidikan hukum terhadap siswa melalui pelajaran PPKn di sekolah. Setiap warga negara nantinya harus tunduk terhadap aturan hukum seperti di bunyikan dalam Undang-undang Dasar 1945 Pasal. 1 ayat (3) Negara Indonesia adalah negara hukum. Bahwa mengenai maksud dari peraturan tersebut setiap warga negara harus tunduk taat kepada aturan hukum tanpa terkecuali dan tidak dibeda bedakan setiap warga negara. Untuk itu kesadaran hukum yang tinggi tidak bisa dilepaskan dari sistem pendidikan dan budaya sekolah yang berkembang pada saat ini. Adapun Pendidikan hukum di negara kita telah masuk di kurikulum pendidikan baik di tingkat SD,SLTP, sedangkan menengah (SMU,SMK,MA) bahkan sampai perguruan tinggi, program tersebut bukan merupakan sesuatu yang baru tetapi diperlukan kembali suatu revitalisasi. Berkaitan dengan hal tersebut, kami mencoba membahas tentang Pentingnya Pendidikan Hukum terhadap siswa melalui pelajaran PPKn.

Menurut H. Asep Suparman (2015 : 54) Jenjang pendidikan diatur dalam Undang-Undang Nomor 20 Tahun 2003 tentang sistem pendidkan nasional. Jenjang pendidikan dasar diatur dalam Pasal (17), jenjang pendidikan menengah diatur dalam Pasal (18), sedangkan jenjang pendidikan tinggi diatur dalam ketentuan Pasal (19). Pendidikan Tinggi (Perguruan Tinggi) diberikan hak untuk menyelenggarakan pendidikan tertentu yang salah satunya pendidikan hukum.

Bahwa Mengingat Judul Penelitian tersebut sangatlah perlu bagi siswa untuk diberikan materi Pentinganya pendidikan hukum terhadap siswa melalui pelajaran PPKn. Peneliti mengambil objek penelitian di SMPS Islam Babusalam, Kec. Bagan sinembah, Kab. Rokan Hilir. Dalam penelitian tersebut peneliti ingin memberikan pemahaman tentang pengetahuan hukum terhadap siswa melaui pelajaran PPKn. Untuk itu peneliti ingin mengetahui sejauh mana siswa menyerap tentang pendidikan hukum, peneliti ingin melihat hal apa saja yang di langgar oleh siswa mengenai aturan di sekolah. Untuk menjawab dari persolan tersebut peneliti langsung berdialog dengan guru PPKn seputar materi pengajaran pendidikan hukum melalui pelajaran PPKn terhadap siswa. Dan dilanjutkan tanya jawab ringan kepada siswa mengenai judul penelitian dan kemudian dilanjutkan dengan memberikan pertanyaan terhadap siswa dalam bentuk angket di kelas VII, VIII, IX.

Dapat kita lihat penomena beberapa kejadian disekolah sekolah lainya, banyak kita dengar banyaknya siswa yang bermasalah, seperti cabut sekolah pada jam pelajaran, terlabat masuk jam sekolah, perkelahian terhadap siswa, melawan guru, tidak menghargai guru, dan pelanggaran kedisiplinan aturan sekolah lainya. Untuk itu dengan adanya penelitian tersebut nantinya dapat menjawab dari setiap masalah yang dilakukan oleh siswa untuk merubah siswa lebih peduli dengan arti sadar tentang pendidikan hukum disekolah melalui pelajaran PPKn. Generasi adalah merupakan aset bangsa yang harus diselamatkan dari perbuatan negatif, untuk itu pemahaman tentang pendidkan hukum harus diberikan sejak di pendidikan sekolah dasar, sekolah menengah pertama, sekolah menengah atas dan sekolah menengah kejuruan. Untuk itu peran dari guru PPKn harapanya harus lebih aktif dalam memberikan ilmu pengetahuan yang seluas luasnya kepada siswa dengan cara memberikan kurikulum standar nasional, edukasi pengetahuan pembelajaran yang mudah dipahami oleh siswa dan kedekatan emosional guru terhadap siswa harus di jalin. Dapat dipahami masa pendidikan menengah pertama merupakan masa puberitas siswa menuju dewasa. Dan tak jarang kita jumpai banyak prilaku siswa yang kurang baik dalam bersikap, baik di lingkungan sekolah maupun di lingkungan masyarakat.

Bahwa mengenai hal tersebut sudah seharusnya juga wali siswa/orang tua dan guru bekerja sama untuk mencari solusi yang terbaik untuk memberikan pemahaman yang baik terhadap siswa, jika terjadi persoalan antara sekolah dengan siswa terkait prilaku siswa yang kurang baik, maka sebaliknya segera mencari solusi pemecahan masalah terhadap siswa, bukan malah saling melaporkan mana yang benar dan yang salah tanpa adanya klarifikasi yang akurat terlebih dahulu, 
Hal : $13-20$

melalui pendidikan hukum dapat memberikan kotribusi yang bermanfaat bagi siswa agar tidak terpengaruh terhadap dunia bebas atau dunia negatif. Untuk itu peneliti tertarik untuk melakukan penelitian lebih dalam guna menemukan jawababan untuk hasil penelitian.

Menurut (Tilaar, H.A. R 2003 : xxiii). Dalam kehidupannya manusia tidak terjadi dalam ruangan kosong, tetapi dalam lingkungan sesama manusia atau ruang kemanusian. Ruang kemanusian itu tidak lain ialah kebudayaan manusia yang terbentang dalam ruang dan waktu. Tidak ada masyarakat (community) tanpa budaya. Oleh karena itu, pendidikan dan kebudayaan merupakan satu kesatuan eksistensial. Proses pendidikan tidak dapat diredusir hanya sebagai proses yang terjadi dalam lembaga sekolah, tetapi sekolah sebagai lembaga sosial merupakan bagian dari proses pendidikan sebagai proses pembudayaan.

Undang-undang No. 20 Tahun 2003 tentang sistem pendidikan nasional, hal ini tertuang pada Pasal (3), isinya: pendidikan nasional berfungsi mengembangkan kemampuan dan membentuk karakter serta peradaban bangsa yang bermatabat dalam rangka mencerdaskan kehidupan bangsa.

Sebaliknya jika dilihat dari amanat Peraturan Pemerintah No. 20 Tahun 2013 tentang UndangUndang Sistem Pendidikan Nasional fungsi dari pendidikan menuntut setiap warga negara untuk mampu meningkatkan harkat dan martabat manusia memiliki keterkaitan yang erat dengan kesadaran diri seseorang sebagai manusia, dalam arti kesadaran nilai-nilai kemanusian.

Faktor-Faktor dan Indikator" Budaya sadar Hukum" dalam konteks budaya sekolah" Menurut Otje Salman (1989 : 53). Dalam meningkatkan kesadaran siswa untuk mematuhi hukum tidak terlepas dari beberapa faktor dan indikator yang mempengaruhinya, diantaranya adalah sebagai berikut:

a. Faktor-faktor: compliance, identification, internalisasi, dan jaminan kepentingan dalam kehidupan di sekolah dan masyarakat.

b. Indikator-indikatornya: Pengetahuan hukum, pemahaman hukum, sikap hukum, dan pola perilaku hukum.

Mengenai faktor-faktor yang mempengaruhi tingkat kesadaran hukum bagi para siswA secara luas adalah; (1) compliance: adalah merupakan suatu faktor kepatuhan yang didasarkan kepada harapan akan sesuatu imbalan dan usaha untuk menghindarkan diri dari hukuman atau sanksi yang mungkin dikenakan apabila seseorang melanggar ketentuan hukum (2) identification adalah suatu faktor kepatuhan terhadap kaidah hukum ada bukan karena nilai intrinsiknya melainkan kepatuhan tersebut tergantung pada baik-buruknya hubungan interaksi individu. (3) internalisasi adalah merupakan faktor dimana seseorang mematuhi kaidah-kaidah hukum yang telah dibuat. (4) jaminan kepentingan-kepentingan para siswa dalam wadah hukum yang ada, jaminan kepastian hukum adalah merupakan faktor yang sangat vital dalam meningkatkan kesadaran hukum yang tentunya hal ini harus direalisasikan terhadap wadah lembaga hukum yang ada dengan dibarengi oleh suatu kinerja moral profesional.

Indikator kesadaran hukum ada 4 (empat) yang tidak dapat dipisahkan dari satu kesatuan indikator yaitu: (1) pengetahuan hukum adalah merupakan pengetahuan seorang siswa mengenai beberapa perilaku tertentu yang diatur oleh hukum. Tentunya yang dimaksud hukum disini adalah hukum tertulis dan hukum yang tidak tertulis. Pengetahuan tersebut berkaitan dengan perilaku yang dilarang ataupun perilaku yang diperbolehkan oleh hukum mengenai peraturan. Contoh yang dilarang disekolah seperti melanggar kedisiplinan aturan sekolah, melawan terhadap guru, membolos pada jam pelajaran disekolah, tidak menghargai guru, merokok, perkelahian dan sebagainya yang sudah di buat oleh sekolah secara tertulis. (2) Pemahaman hukum merupakan informasi yang dimiliki seorang siswa mengenai isi peraturan dari suatu hukum tertentu. Dalam arti lain bahwa hukum adalah suatu pengertian terhadap isi dan tujuan hukum dari suatu peraturan dalam suatu hukum tertentu, tertulis maupun tidak tertulis, serta manfaatnya. (3) Sikap Hukum akan melibatkan pilihan nilai-nilai hukum yang ada dalam peraturan sehingga akhirnya para siswa menerima hukum berdasarkan penghargaan terhadapnya. (4) Pola prilaku hukum adalah fungsi dari kedudukan hukum bagi para siswa untuk memberikan kesadaran hukum dalam lingkungan sekolah dan masyarakat.

Menurut Satjipto Raharjo (2009 : vii). Pendidikan hukum pertama kali diperkenankan kepada masyarakat pribumi kepada masyarakat pribumi oleh pemerintah kolonia belanda yang pada masa itu dikenal dengan rechtshogeschool dan sejak saat itu pendidikan hukum sepanjang sejarah perberkembanganya.

Tujuan Pendidikan Menurut Yuniastuti.( 2010 : 40 ). Ekstensi, Moral Dalam Pendidikan. Pendidikan Nasional diarahkan untuk mampu menciptakan pribadi (generasi penerus). Yang 
Hal : $13-20$

bermoral, mandiri, matang, dan dewasa, jujur, berakhlak mulia, berbudi pengerti luhur, santun, tahu malu. Serta mementingkan kepentingan bangsa dan tidak mementingkan pribadi atau golongan saja.

\author{
METODE PENELITIAN \\ Tempat Penelitian \\ Penelitian ini dilakukan di Sekolah SMPS Islam Babussalam, Kec. Bagan Sinembah. \\ Waktu Penelitian \\ Penelitian ini dilaksanakan dengan waktu mulai bulan April 2019 - September 2019.
}

Jenis Penelitian

Berdasarkan sifatnya penelitian ini menggunakan jenis penelitian Diskriptif Kualitatif, Penelitian dengan cara mengamati dan memberikan angket pelajaran tentang pendidikan hukum terhadap siswa di kelas VII, VIII, IX. Sedangkan teknik pengumpulan data menggunakan, observasi, wawancara, dokumentasi dan angket siswa.

\title{
Sumber data
}

\section{Data Primer}

Data Primer yang digunakan dalam penelitian ini berupa melakukan observasi dengan memberikan angket terhadap siswa kelas VII, VIII, IX, wawancara terhadap guru PPKn, Kepala Sekolalah, dan Korwil Dinas Pendidikan, Kec. Bagan Sinembah.

\section{Data Sekunder}

Data Skunder yang digunakan dalam penelitian menggunakan data pendukung untuk memperkuat hasil penelitian berupa referensi buku, jurnal, undang-undang dan dokumentasi lainya untuk mendukung dalam penelitian.

\section{Analisis Data}

Teknik analisis data dilakukan secara deskriptif kualitatif dengan menggunakan model Miles dan Huberman. Model ini dilakukan dalam 3 tahap: (1) Reduksi data yaitu (a) meringkaskan data kontak langsung dengan orang, kejadian dan situasi di lokasi penelitian, (b) pengkodean, (c) pembuatan catatan objetif, (d) membuat catatan reflektif, (e) membuat catatan marginal, (f) penyimpana data, (g) pembuatan memo, (h) analisis antarlokasi, dan (i) pembuatan ringkasan sementara antar lokasi. Tahap (2) Display Data dengan menyusun teks naratif, Tahap (3) Verifikasi yaitu tahap penarikan kesimpulan.

\section{HASIL PEMBAHASAN}

Berdasarkan hasil penelitian tentang kajian studi pentingnya pendidikan hukum terhadap siswa melalui pelajaran PPKn ( Studi SMPS Islam Babussalam, Kec. Bagan Sinembah). Mengenai beberapa penjelasan hasil penelitian terkait mendiskripsikan pendidikan hukum terhadap siswa dapat di proleh dari hasil sebagai berikut: wawancara terhadap Guru PPKn, Kepala sekolah, Korwil Bagan Sinembah dan angket terhadap siswa kelas VII, VIII, IX.

Tabel: Hasil Angket Diberikan Terhadap Siswa Tentang Pendidikan Hukum:

\begin{tabular}{cccccccc}
\hline \multirow{2}{*}{ NO } & KELAS & SISWA & \multirow{2}{*}{ ANGKET } & SR & KETERANGAN & SL & TP \\
\hline 1 & VIII & 14 & 10 & $7 \%$ & $17 \%$ & $12 \%$ & $25 \%$ \\
2 & VIII A & 15 & 10 & $9 \%$ & $30 \%$ & $10 \%$ & $19 \%$ \\
3 & VIII B & 15 & 10 & $12 \%$ & $16 \%$ & $13 \%$ & $15 \%$ \\
4 & IX A & 14 & 10 & $14 \%$ & $23 \%$ & $14 \%$ & $20 \%$ \\
5 & IX B & 10 & 10 & $9 \%$ & $30 \%$ & $22 \%$ & $30 \%$ \\
& & HASIL & & $10,2 \%$ & $23,2 \%$ & $14,2 \%$ & $17,8 \%$ \\
\hline
\end{tabular}

Dapat dilihat dari hasil angket siswa menunjukkan bahwa pembelajaran pendidikan hukum terhadap siswa melalui pelajaran pendidikan pancasila dan kewarganegaraan (PPKn). Materi tersebut sudah dipelajari semenjak di bangku sekolah dasar, sekolah menengah dan sekolah menengah pertama (SD, SMP,SMA/SMK). Pendidkan Hukum melalui pelajaran materi PPKn telah dapat merubah paradigma siswa tentang pemahaman pendidikan hukum. Bahwa siswa merupakan generasi penerus bangsa yang harus diberikan pemahaman intelektual tentang generasi yang taat pada aturan hukum. Dikarenakan cikal bakal bangsa ini menginginkan kehadiran pemimpin-pemimpin yang bersih dan tunduk kepada aturan yang berlaku. Didalam kepribadian seseorang harus ditanamkan nilai-nilai budi pengerti yang luhur untuk memberikan kontribusi besar terhadap negara 
Hal : $13-20$

sesuai dengan amanat peraturan perundang-undangan. Dapat dilihat dalam angket siswa bahwa yang melakukan Sering total: ( $10,2 \%)$, Kadang-kadang total: $(23,2 \%)$, Selalu total: $(14,2 \%)$, dan Tidak perna: ( $17,8 \%$ ) .Dapat disimpukan dari angket bahwa siswa cukup memahami pelajaran tentang hukum dapat dilihat dari keterangan angket. . Berdasarkan hasil tersebut peneliti mengambil kesimpulan bahwa yang mempengarui siswa terhadap pelanggaran aturan kedisiplinan sekolah sesuai dengan pertanyaan pada angket yang menjadi latar belakang pada penelitian. Bahwa materi pembelajaran terkait tentang hukum terhadap siswa banyak yang memahami, untuk itu sebenarnya siswa hanya kurang kesadaran dalam penerapkanya dikehidupan sehari hari dan kurang menginflementasikan dalam masyarakat, khususnya dalam kepribadian siswa. Untuk memberikan pembelajaran terhadap siswa peran dari guru PPKn harus lebih aktif dan dapat memahami dari setiap persoalan siswa, untuk itu butuh kedekatan emosional untuk mendekatkan diri terhadap siswa. Mengenai kurikulum pembelajaran harus standar pendidikan dalam pengajaran disekolah.

Menurut Kosasih Djahir (2000 : 2). Mengemukakan penyelenggaraan program "Pendidikan Hukum" dalam lingkungan lembaga pendidikan disesuaikan dengan tujuan pendidikan pada setiap jenis dan jenjang sekolah.

Sedangkan muatan materi pembelajaran pendidikan hukum terhadap siswa melaui pelajaran Pendidikan Pancasiala dan Kewarganegeraan (PPKn) disekolah dapat diberikan dengan cara banyak memberikan contoh-contoh kesadaran hukum seperti dilarang berkelahi, menghargai guru disekolah, tidak melanggar aturan kedisiplinan sekolah, tidak terpengaruh dengan pergaulan bebas, tidak membolos sekolah pada pelajaran berlangsung, tidak merokok, menjalankan hukuman apabila diberikan sangksi sekolah dan pada intinya berkaitan tentang pendidikan hukum disekolah dan masyarakat. dan materi tersebut juga dapat dikaitkan dengan materi pendidkan agama dan sosiologi interaksi dimasyarakat.

Menurut Satjipto Raharjo (2005 : 8). Apabila kita ingin menjadikan pendidikan hukum sebagai avant garde dari perubahan kultur berhukum di indonesia, maka sebaliknya kita berani dengan gagasan "Pendidikan hukum berbasis manusia dan kemanusian". Melaui cara tersebut maka seluruh kurikulum juga akan dirancang kembali menuju kepada gagasan baru tersebut, termasuk isinya. Sejalan dengan yang diutakan oleh sacipto Raharjo.

Menurut peneliti penerapan muatan materi pendidkan hukum dapat di jalankan dengan baik di sekolah asalkan dengan cara metode yang baik diantaranya yaitu dengan merubah manusia untuk memahami arti sebuah hukum dengan memberikan kurikulum standar nasional yang selalu berkembang oleh zaman, wawasan guru PPKn yang cukup luas dalam menyampaikan materi, dan pendekatan emosional guru terhadap siswa harus terjalin untuk memberikan minat belajar bagi siswa. Untuk menyampaikan materi tentang pendidikan hukum maka guru dan siswa cara yang paling tepat untuk pembelajaran pendidikan hukum di kelas dan luar kelas. Khususnya guru PPKn dapat memberikan metode terhadap siswa dengan cara diskusi, ceramah dan simulasi contoh yang mudah dipahami oleh siswa di sekolah seperti contoh diatas yang sudah diterangkan sebelumya.

Muatan Pendidikan Pancasila dan Kewarganegaraan tidak terlepas dari "Pendidikan Hukum" sesuai dengan amanat Undang-undang Nomor 20 Tahun 2003, Tentang Sistem Pendidikan Nasional yang tertuang dalam pasal (1). Pendidikan adalah usaha sadar dan terencana untuk mewujudkan suasana belajar dan prose pembelajaran agar peserta didik secara aktif mengembangkan potensi dirinya untuk memiliki kekuatan spiritual keagamaan, pengendalian diri, kepribadian, kecerdasan, akhlak mulia, serta keterampilan yang diperlukan dirinya, masyarakat, bangsa dan negara. Pasal (2) Pendidikan nasional adalah pendidikan yang berdasarkan pancasila dan Undang-Undang Dasar Negara Republik Indonsesia tahun 1945 yang berakar pada nilai-nilai agama, kebudayaan nasional indonesia dan tanggap terhadap tuntutan perubahan zaman. Mengenai pengaturan pendidikan juga diatur dalam Undang-Undang Dasar 1945 Pasal (31) ayat (1) Setiap warga negara berhak mendapat pendidikan. Jika dilihat dari beragam aturan negara yang di buat berbentuk undang-undang atau peraturan lainya cukup jelas negara menginginkan pemerataan pendidikan dan kualitas pendidikan para generasi bangsa yang bermutu dan memiliki didikasi pengetahuan yang luas untuk kemajuan bangsa dan negara. Untuk itu sebaliknya negara menginginkan generasi yang mempunyai prilaku yang baik terutama dipendidikan sekolah dasar, sekolah menengah pertama dan sekolah menengah atas. Pendidikan hukum disekolah perlu ditanamkamkan disekolah sejak dini agar para siswa dapat mempilah-pilah perbuatan buruk dan baik.

Hasil wawancara dengan Guru PPKn Menerangan: Bahwa mengenai pengejaran siswa disekolah sudah sesuai dengan standar pendidikan dan mengacuh kepada kurikulum pendidikan, 
$\mathcal{H a l}: 13-20$

guru dalam memberikan pengetahuan pengajaran tentang pendidikan hukum disekolah sudah sering diberikan pembelajaran disekolah, apalagi pendidikan hukum sangat diperlukan bagi siswa mengingat banyaknya kronologis persoalan siswa yang bermasalah bahkan mengarah kepada pergaulan bebas dan prilaku siswa yang negatif. Untuk itu selalku guru harus memberikan pengetahuan yang luas terhadap siswa mengenai bahaya dampak dari prilaku yang tidak baik terhadap siswa. Guru dalam memberikan pengetahuan tentan pendididikan hukum butuh kesabaran dan kedekatan emosional mengingat siswa pada usia tersebut merupakan masa puberitas yang harus diselamatkan dari pergaulan negatif. Untuk itu seorang pendidik harus prosional dalam mengajar dan dapat terjun langsung terhadap siswa untuk memberikan contoh-contoh yang baik terhadap siswa tandasnya diutarakan pada saat wawancara pada tanggal ( 10 Maret 2019 ).

Hasil wawancara dengan Kepala Sekolah menerangkan: Bahwa pihak sekolah telah menerapkan pendidikan dengan standar pendidikan yang baik, mengenai oknum siswa yang masih bermasalah pihak sekolah akan berjuang keras untuk mendidik siswa agar lebih disiplin dalam setiap prilaku dalam kehidupanya. Sekolah mempunyai aturan yang tegas dalam kedispinan disekolah diantaranya yaitu adanya aturan yang harus dijalani dari setiap siswa, sedangkan bagi siswa yang bermasalah pihak sekolah memberikan penyelesaian dengan cara musyawarah mufakat berbentuk teguran nasehat sedangkan jika masih bermasalah teguran tertulis yang disampaikan kepada wali siswa untuk mencari solusi penyelesaian terbaik. Jika masih bermasalah maka pihak sekolah mengambil sikaf dengan mengeluarkan siswa. Dalam persoalan siswa tersebut mungkin hampir setiap sekolah mempunyai aturan tegas terhadap siswa. Akan tetapi untuk masalah siswa yang terlalu patal mengenai pelanggaran kedisiplinan sekolah masih sebatas wajar layaknya siswa yang puberitas. Pihak sekolah akan mengambil langkah dengan cara memberikan metode yang pas dalam pengajaran disekolah tandasnya dalam memberikan keterangan pada tanggal ( 9 Maret 2019 ).

Hasil wawancara dengan Pihak Korwil Kecamatan Bagan Sinembah menerangkan: Bahwa pihak korwil selaku kordinator pendidikan didaerah setempat sangat mendukung apabila adanya pihak yang mau meneliti tentang pendidikan, menurut beliau pendidikan adalah merupakan suatu keharusan yang harus diselamatkan untuk merubah paradigma yang lebih baik terhadap generasi, melalui pendidikan akan mendapatkan sumber daya manusia yang berkualitas. Bahkan bila perlu diadakan sosialisasi rutin disetiap sekolah-sekolah untuk memberikan materi pentingnya pendidikan hukum melalui pelajaran PPKn atau kesadaran hukum terhadap siswa disekolah. Mengingat banyak dilihat oknum siswa yang tidak mencerminkan selaku siswa dan terpengaruh terhadap pergaulan negatif, untuk itu beliau menginginkan kerja sama yang baik untuk memberikan yang terbaik untuk dunia pendidikan dalam berbagai ilmu pengetahuan yang luas dan dapat menjadikan kontribusi yang besar bagi pendidikan tandasnya diutarakan pada tanggal ( Maret-April 2019 ).

Menurut Ki Hajar Dewantara (1974 : 14 ). Beliau merupakan tokoh pendidikan nasional, pengertian pendidikan sebagai daya upaya untuk memajukan pertumbuhanya budi pengerti (penguatan batin, karakter), pikiran (intelektual dan tumbuh anak). Dalam taman siswa, tidak boleh dipisahkan bahagian-bahagian itu agar memajukan kesempurnaan hidup, kehidupan dan penghidupan anak-anak yang kita didik, selaras dengan dunianya.

Menurut Gusdiwo Rinoyo, Dkk (2016 : 12). Pengetahuan hukum memberikan pengaruh terhadap kepatuhan siswa dalam melaksanakan tata tertib. Oleh karena itu pengetahuan hukum yang dimiliki oleh siswa harus ditingkatkan. Pengetahuan hukum yang benar akan menjadi modal yang sangat penting dalam pembembentukan hukum disekolah dan lingkungan masyarakat.

Berdasarkan penjabaran diatas mengenai pendididikan menurut penulis pendidikan siswa harus sesuai dengan jamanya dan sesuai dengan pertumbuhan anak semenjak dini untuk proses perkembangan dari anak-anak menuju kedewasaanya. Hal tersebut tidak terlepas dari interaksi sekolah dan masyarakatnya. Sebaliknya pertumbuhan jasmani dan rohani siswa akan merubah karakter dari anak tersebut.

Menurut Muntoha (2016 : 94). Mengemukakan seiring bergantinya kebijakan di bidang pendidikan, sistem kurikulum dan lainya merupakan cerminan konsep hukum darinya, di mana citacita bangsa kita yang ada dalam pembukaan UUD 1945, untuk mencerdaskan kehidupan bangsa harus dibuat aturan dibidang pendidikan. Karena untuk bisa mengubah masyarakat atau bangsa indonesia menjadi manusia yang cerdas harus diubah melalui hukum yaitu norma-norma hukum yang ada diperaturan perundang-undangan.

Untuk itu mengenai pendapat muntaha, menurut peneliti persoalan pendidikan harus segera dituntaskan dengan sebaik mungkin oleh negara sebagai penyelenggara pendidikan skala nasional, untuk itu penerapan pendidikan di sekolah harus menpunyai kualitas yang baik guna memacu sumber daya manusia yang dapat bersaing dengan negara lain, untuk menjalankan pendidikan yang 
Hal : $13-20$

berkualitas harus sejalan dengan kebijakan pemerintah. Inflementasi dari pendidikan hukum harus sesuai dengan nilai-nilai kehidupan di masyarakat yang selalu berkembang dan dinamis. Memang kalau kita cermati sistem pendidkan di indonesia selalu berubah-ubah untuk itu butuh kedewasaan untuk mengukur dari sebuah arti pendidikan, perubahan tersebut dikarenakan sistem pergantian pemerintahan, maka berganti pula sistemnya.

Menurut Ikhsan (2017 : 54). Dalam proses pembelajaran pendidikan pancasila dan kewarganegaraan, selain alat media- media, masyarakat merupakan sumber dan media utama dalam pembelajaran pendidikan pancasila dan kewarganegaraan. Dalam masyarakat, siswa dapat melihat langsung proses sosial yang sedang berlangsung kepada siswa diperkenalkan konsep geograpis setempat, masalah kehidupan kelompok, proses dan mekanisme pemerintahan, aktifitas produksi dan distribusi barang dan jasa, adat istiadat setempat.

\section{Kesimpulan}

Menurut Peneliti pendidikan hukum melalui pelajaran Pendidikan Pancasila dan Kewarganegaraan (PPKn) disekolah dapat membawa imflementasi perubahan pendidikan di sekolah, karena mata pelajaran PPKn memfokuskan bidang pengetahuan untuk pembentukan warga negara yang mampu memahami hak dan kewajiban dari setiap warga negara indonesia, khususnya bidang pengetahuan pendidikan hukum sesuai dengan amanah Pancasila dan UUD 1945. Dan Peraturan Presiden tentang Nomor 87 Tahun 2017 Tentang Penguatan Pendidikan Karakter pada Pasal (1) menerangkan "Penguatan pendidikan karakter yang selanjutnya disingkat PPK adalah gerakan pendidikan untuk memprkuat karakter peserta didik melalui harmonisasi olah hati, olah rasa, olah pikir, dan olah raga dengan melibatkan dan kerja sama antara satuan pendidikan, keluarga, dan masyarakat sebagai bahagian dari Gerakan Nasional Revolusi Mental (GNRM)". Untuk itu dapat disimpulkan bahwa pendidikan hukum harus selalu diberikan kepada setiap siswa disekolah, untuk memberikan dampak perubahan kepada siswa agar tidak keluar dari subtansi seorang siswa yang mempunyai didikasi kurang baik, siswa yang baik harus taat terhadap aturan hukum. Untuk itu harapannya pentingnya pendidkan hukum terhadap siswa melalui pelajaran PPKn disekolah harus diberikan sejak di sekolah. Penerapan tersebut dapat diinflementasikan dalam kehidupan sehari-hari setiap siswa. Sedangkan guru dalam pengajaran harus mempunyai metode pengajaran sesuai dengan standar kurikulum pendidikan.

\section{Ucapan Terima Kasih}

Penulis mengucapkan banyak terima kasih kepada DRPM Ristek Dikti atas bantuan dana untuk penelitian dosen pemula tahun 2018 dan kepada pihak SMP Swasta Islam Babussalam yang telah memberikan data dan informasi dalam penelitian ini.

\section{DAFTAR PUSTAKA}

[1]. Dewantara, Ki Hajar, 1977. Karya Ki Hajar Dewantara, Yogyakarta:Majelis Luhur Persatuan Taman Siswa.

[2]. Tilaar, H.A. R, 2003. Kekuasaan \& Pendidikan, Indonesia Tera, cetakan ke-1.

[3]. Rahardjo, Satjipto, 2009. Pendidikan Hukum Sebagai Pendidikan Manusia, Genta Publishing, Yogyakarta.

[4]. Rahardjo, Satjipto, Pendidikan Hukum Sebagai Pendidikan Manusia, Program Studi Magister IImu Hukum, Fakultas Hukum Universitas Diponogoro Jurnal Law Reform, Vol. 1, No.1, Halaman: 8:2005.

[5]. Undang-Undang Dasar 1945

[6]. Undang-Undang No. 20 Tahun 2003, Tentang Sistem Pendidikan Nasional.

[7]. Otje Salman, 1989. Beberapa aspek Sosiologi Hukum, Alumni Bandung.

[8]. Kosasih Djahiri, 2000. Strategi Pembelajaran PPKn Era Reformasi Menuju Indonesia Baru.

[9]. Suparman, asep, Pendidikan Hukum Humanistik, Sekolah Tinggi Ilmu Bandung, Jurnal Wawasan Hukum, Vol.1, No.1, Februari, Halaman: 54, 2015. 
Hal : $13-20$

[10]. Muntoha, Pendidikan Dalam Perspektif Hukum (Antara Harapan dan Realita), Jurnal Madaniyah, Vol. 1 Edisi X Januari. ISSN 2086-3462, Halaman: 94:2016.

[11]. Ihksan, 2017. Kecendrungan Global Dalam Proses Pembelajaran Pendidikan Pancasila dan Kewarganegaraan dan Kewarganegaraan di Sekolah, Jurnal Pancasila dan Kewarganegaraan, Vol. 2, No. 2, Juli, ISSN 2527-7057 (Online), ISSN 2545-2683 (Printed). Halaman: 54:2017.

[12]. Rinoyo Gusdiwo, dkk, Hubungan Antara Pengetahuan Hukum Dengan Tingkat Kepatuhan Terhadap Tata Tertib Sekolah Pda Siswa Kelas X SMA Negeri 4 Yogyakarta, Fakultas Ilmu Sosial, Universitas Negeri Yogyakarta, Halaman: 12:2016.

[13]. Yuniastuti, Eksistensi, Moral dalam Pendidikan, Jurnal Pendidikan Pancasila dan Kewarganegaraan, Th 23, Nomor 2, Agustus, Halaman:40:2010. 